\title{
PROSPEK DAN TANTANGAN USAHATANI TEMBAKAU MADURA
}

\author{
Fuad Hasan ${ }^{1)}$ dan Dwidjono Hadi Darwanto ${ }^{2)}$ \\ 1) Jurusan Agribisnis Fakultas Pertanian Universitas Trunojoyo \\ 2) Prodi Agribisnis Fakultas Pertanian Universitas Trunojoyo \\ E-mail: fuad.hsn@gmail.com
}

\begin{abstract}
Tobacco has an important role in the socio-economic life of the community, such as the State in the form of tax revenue and foreign exchange earnings, employment, the income of farmers, laborers, and merchants, as well as revenue. But on the other hand, under the pretext of health, development and trading of tobacco began to get legalized opposition through regulations. This has an impact on the survival of tobacco farming, which in turn have an impact on the welfare of farmers. This paper aims to discuss the prospects and challenges facing tobacco farmers in Madura. In addition, tobacco farmers face problems: marketing systems, productivity, and bargaining position. Alternative solutions are 1) reduction in acreage planted;2) replacement of plants; 3) low nicotine tobacco cultivation; 4) diversification of derivative products; 5) optimization of the institutional
\end{abstract}

Keyword: tobacco, prospect, challenge

\section{PENDAHULUAN}

Tembakau merupakan salah satu komoditas penting di Indonesia. Peran tembakau dan industri hasil tembakau dalam kehidupan sosial ekonomi masyarakat adalah penerimaan negara dalam bentuk cukai dan devisa, penyediaan lapangan kerja, sebagai sumber pendapatan petani, buruh, dan pedagang, serta pendapatan daerah. Penerimaan negara dari cukai hasil tembakau mengalami peningkatan secara signifikan yaitu dari Rp32,6 triliun pada tahun 2005 menjadi Rp65,4 triliun pada tahun 2011 (Tabel 1). Pada kegiatan on farm komoditas tembakau mampu menyerap tenaga kerja sebesar 21 juta jiwa sedangkan di kegiatan off farm sebesar 7,4 juta jiwa (Ditjen Perkebunan, 2009).

Jawa Timur merupakan propinsi penghasil tembakau terbesar di Indonesia (58,2\%). Salah satu daerah di Propinsi Jawa timur yang penduduknya banyak membudidayakan tanaman tembakau adalah pulau Madura yang meliputi tiga kabupaten dari empat kabupaten yang ada yaitu: Kabupaten Sampang, Pamekasan, dan Sumenep. Total luas lahan tembakau Madura mencapai 51,5\% pada tahun 2006 dan $34,8 \%$ pada tahun 2010 terhadap total luas lahan tembakau di jawa timur. Tembakau di Madura dibudidayakan secara turun temurun oleh masyarakat Madura karena dibandingkan dengan komoditas lain, tembakau memberikan harapan keuntungan yang lebih besar.

Tabel 1. Perkembangan Realisasi Penerimaan Cukai Hasil Tembakau (Trilliun Rupiah)

\begin{tabular}{cc}
\hline Tahun & Penerimaan \\
\hline 2005 & 32,6 \\
2006 & 37,1 \\
2007 & 43,5 \\
2008 & 49,9 \\
2009 & 53,3 \\
2010 & 63,2 \\
2011 & 65,4 \\
\hline
\end{tabular}

Sumber: Publikasi Depkeu

Tembakau dibudidayakan mulai bulan April sampai Agustus di lahan sawah, tegal, dan pegunungan dengan jenis varietas lokal (prancak). Kabupaten Pamekasan mempunyai lahan tembakau paling luas dibandingkan dua kabupaten lainnya (Tabel 2). 
Fuad Hasan, Dwidjono H. D. : Prospek Dan Tantangan Usahatani Tembakau Madura...

Tabel 2. Luas Lahan (Ha) dan Produksi Tembakau di Madura dan Jawa Timur 2006-2010

\begin{tabular}{lrrrrrrrr}
\hline \multirow{2}{*}{ Kabupaten } & \multicolumn{7}{c}{ Tahun } \\
\cline { 2 - 8 } & \multicolumn{2}{c}{2007} & \multicolumn{2}{c}{2008} & \multicolumn{2}{c}{2009} & \multicolumn{2}{c}{2010} \\
\cline { 2 - 9 } & \multicolumn{1}{c}{ Luas } & Produksi & \multicolumn{1}{c}{ Luas } & Produksi & \multicolumn{1}{c}{ Luas } & Produksi & \multicolumn{1}{c}{ Luas } & Produksi \\
\hline Sampang & 3.119 & 3.620 & 2.056 & 1.775 & 932 & 2.297 & 1.429 \\
Pamekasan & 31.367 & 16.625 & 29.376 & 17.057 & 32.205 & 12.270 & 25.893 & 10.242 \\
Sumenep & 19.412 & 8.930 & 23.355 & 13.210 & 13.419 & 6.575 & 9.836 & 3.139 \\
Jatim & 108.701 & 78.343 & 109.408 & 77.852 & 112.007 & 76.278 & 109.250 &
\end{tabular}

Sumber: BPS, 2011

Tabel 3. Dana Bagi Hasil Cukai Hasil Tembakau Madura Tahun 2010-2012 (Rupiah)

\begin{tabular}{lccc}
\hline \multirow{2}{*}{ Tahun } & \multicolumn{3}{c}{ Kabupaten } \\
\cline { 2 - 4 } & Sampang & Pamekasan & Sumenep \\
\hline 2010 & 6.437 .724 .381 & 18.939 .623 .381 & 13.634 .522 .381 \\
2011 & 6.318 .031 .578 & 23.828 .852 .235 & 13.009 .313 .588 \\
2012 & 8.302 .956 .321 & 26.552 .667 .916 & 18.027 .736 .926 \\
\hline
\end{tabular}

Sumber: Peraturan menteri keuangan(PMK) No:66/PMK.07/2010, PMK No.96/PMK.07/2011, PMK No.46/PKM.07/2012

Usahatani tembakau menyumbang kurang lebih $60-80 \%$ terhadap pendapatan petani di Madura (Anonim, 2007). Bagi pemerintah, komoditas tembakau memberikan kontribusi terhadap Pendapatan Asli Daerah (PAD) yang cukup besar melalui pengembalian cukai rokok dari pemerintah pusat. Oleh karena itu, tembakau dijadikan sebagai komoditas unggulan terutama di Kabupaten Pamekasan dan Sumenep.

Data ketenagakerjaan di Pamekasan tahun 2011 menunjukkan bahwa industri sektor pertembakauan mampu menyerap tenaga kerja sebanyak 4.059 orang, ini belum termasuk tenaga kerja di masyarakat pada saat musim panen yang jumlahnya jauh lebih besar. Data yang lain menyebutkan bahwa jumlah petani yang menanam tembakau sebanyak $95.895 \mathrm{KK}$, maka tenaga kerja yang terserap dalam budidaya tembakau ini kurang lebih sebanyak 287.685 orang.

Tembakau Madura mempunyai peranan yang sangat penting dalam industri rokok yaitu peranannya dalam racikan sigaret kretek. Hampir semua rokok kretek menggunakan tembakau madura dalam racikan (blend) tembakaunya (Akehurst,1983). Komposisi tembakau madura dalam rokok kretek berkisar antara 14-22\%, tembakau temanggung sedikit lebih banyak, tembakau virginia hampir seimbang dengan tembakau madura, dan tembakau lainnya dibutuhkan dalam jumlah sedikit.

\section{HASIL DAN PEMBAHASAN}

Pembahasan permasalahan yang mempengaruhi secara langsung dan tidak langsung pengusahaan tembakau pada umumnya dapat dibagi dua, yaitu: masalah eksternal dan masalah internal.

\section{Masalah Eksternal}

Penentangan Kelompok Anti Rokok. Pada satu sisi, tembakau memberikan sumbangan yang tidak sedikit bagi perekonomian baik terhadap masyarakat maupun negara. Namun demikian pada sisi lain, produk hasil tembakau yang ada pada saat ini bisa mengganggu kesehatan dan lingkungan hidup. Oleh karena itu kehadiran produk-produk tembakau, terutama rokok, mulai ditentang oleh masyarakat. Penentangan ini terjadi di Negara-negara maju terutama Amerika Serikat (AS) dan Uni Eropa (UE). Pemerintah AS dan UE bahkan tidak lagi memberikan dukungan kepada pengembangan produksi tembakau, baik secara politis, ekonomi (proteksi, subsidi, dll) maupun hukum (restriksi penggunaan tembakau).

Pemerintah Indonesia berupaya menekan laju produksi rokok melalui beberapa kebijakan sekaligus, diantaranya yaitu (a) menaikkan harga jual eceran (HJE) sebesar 7\% per Maret 2007; (b) penetapan tarif spesifik rokok antara 3-7 rupiah per batang rokok untuk rokok golongan I, Rp5 untuk golongan II, dan 
Rp3 untuk golongan III sesuai yang tercantum dalam Permen Keu No. 118/PMK.04/2006 tentang Kebijakan Cukai 2007 (Anonim 2006); (c) UU No. 39 Tahun 2007 tentang batas cukai maksimum mencapai 57\%; (d) PP No 81 tahun 1999 tentang Pengamanan Rokok bagi Kesehatan yang disempurnakan dengan PP No. 38 tahun 2000; (e) PP No. 19 tahun 2003 tentang pembatasan kadar nikotin rokok dan (f) Pergub DKI Jakarta No 75 Tahun 2005 tentang larangan merokok di tempat umum. Kedepan, kebijakan ini akan diikuti oleh daerah lainnya. Kebijakan lain yang dilakukan pemerintah adalah pengendalian/pelarangan iklan rokok.

Pemerintah telah mengesahkan

Rancangan Peraturan Pemerintah (RPP) tentang pengendalian produk tembakau guna mendukung pelaksanaan pasal tembakau dalam Undang-undang kesehatan (UU No.36 Tahun 2009) menjadi Peraturan Pemerintah No. 109 Tahun 2012. Beberapa isi PP tersebut adalah tentang 1) pengawasan pengaturan kawasan tanpa rokok; 2) peringatan berupa gambar pada kemasan produk tembakau; 3) larangan menjual produk tembakau kepada anak-anak (usia di bawah 18 tahun); 4) larangan total untuk iklan, sponsor, dan promosi di media masa; 4) larangan menjual rokok batangan; 5) pengujian kadar nikotin dan tar pada tiap batang rokok. Selain itu, ada tuntutan global yang menyangkut kandungan residu pestisida dan bahan kimia lainnya dan tekanan dari lembaga swasta internasional.

Konvensi Kerangka Pengendalian Tembakau atau Framework Convention on Tobacco Control (FCTC), sebagai hukum internasional yang telah diresmikan tahun 2005, maka posisi kelompok anti tembakau menjadi makin kuat. Konvensi tersebut merupakan perjanjian kesehatan internasional pertama yang perundingannya diprakarsai oleh Badan Kesehatan Dunia (WHO). Tujuannya adalah untuk melindungi generasi sekarang dan mendatang dari kerusakan kesehatan, konsekuensi sosial, lingkungan, dan ekonomi karena mengkonsumsi tembakau. Negaranegara yang telah meratifikasi FCTC terikat secara hukum antara lain dalam hal peningkatan cukai rokok, pengaturan secara komprehensif mengenai iklan, promosi, dan sponsor rokok, serta penyelundupan.
Sistem Tataniaga. Petani menjual hasil panen tembakaunya dalam bentuk krosok, rajangan, atau dalam bentuk pohon yang belum dipanen dengan sistem tebasan. Panjang dan tertutupnya tataniaga tembakau di Madura sering merugikan petani. Gambar 1 menunjukkan hubungan kelembagaan tataniaga di Madura.

Paling tidak ada tujuh tata hubungan antar pelaku ekonomi dan pemerintah. Tatahubungan tersebut ada yang sifatnya mengikat (kontraktual) dan ada pula yang sifatnya tidak mengikat (transaksional) serta pola hubungan yang sifatnya pembinaan oleh Pemerintah Daerah terhadap anggota masyarakat di daerahnya. Secara lebih jelasnya diuraikan sebagai berikut :

1. Nomor 1, menunjukan pola hubungan koordinatif antara Gudang Pabrik dengan Pemkab (Bupati). Walaupun Pemkab (Bupati) berada pada posisi yang lebih tinggi, tetapi Bupati tidak bisa melakukan suatu instruksi untuk memaksakan suatu kebijakan kepada gudang pabrik.

2. Nomor 2, menunjukan pola hubungan kontraktual antara pabrik rokok (gudang pabrik) dengan ranting atau ranting. Pola hubungan ini sifatnya mengikat karena anggota ranting adalah para ranting yang sudah ditentukan secara tepat oleh gudang pabrik. Ranting bertugas memasok tembakau dengan komitmen yang sudah dibangun dari awal sebelum pembukaan gudang. Hanya ranting yang bisa memasok tembakau ke gudang pabrik.

3. Nomor 3, menunjukkan pola hubungan kontraktual antara ranting dengan bandol yang sifatnya mengikat. Bandol adalah para tengkulak sebagai kepanjangan tangan dari ranting yang diberi pinjaman modal oleh ranting dan memiliki kewajiban untuk menyetor tembakau kepada ranting.

4. Nomor 4, pola hubungan transaksional yang sifatnya tidak mengikat (bebas). Bandol tidak ada kewajiban untuk menjual tembakaunya ke ranting tertentu. Bandol bebas menjual tembakaunya kepada ranting yang mau membeli dengan harga tertinggi.

5. Nomor 5, pola hubungan jual beli biasa yang sifatnya transaksional antara bandol dengan petani yang tidak mengikat satu dengan lainnya. Antara petani dengan bandol mereka saling independen sehingga disana akan terjadi tawar-menawar harga 
Fuad Hasan, Dwidjono H. D. : Prospek Dan Tantangan Usahatani Tembakau Madura...

yang tunduk terhadap mekanisme pasar. Petani bebas menetukan bandol yang membeli dengan harga tertinggi

6. Nomor 6, pola hubungan transaksional yang sifatnya tidak langsung antara petani sebagai produsen tembakau di satu sisi dengan gudang pabrik sebagai pembeli tembakau di sisi yang lain. Hasil pengamatan di lapangan dalam prakteknya tidak mungkin petani langsung membawa tembakaunya untuk dijual ke gudang.

7. Nomor 7 , pola hubungan pembinaan dari Pemerintah Kabupaten terhadap anggota masyarakat yang tidak lain adalah para pelaku ekonomi tembakau, mulai dari pabrik rokok sampai petani.

Petani tidak bisa menjual hasil panennya langsung ke gudang rokok sehingga menyebabkan panjangnya rantai pemasaran dan perbedaan harga yang relatif besar antara yang diterima petani dengan lembaga pemasaran lainnya dan gudang pabrik rokok (Tabel 4 dan
Tabel 5). Gudang pabrik rokok selain memanfaatkan tembakau untuk keperluan produksi roko sendiri, tetapi juga mejual tembakau rajangannya ke luar negeri. Gudang pabrik rokok menerima harga lebih besar karena menyelenggarakan pembelian dari ranting sehingga harus menanggung biaya restribusi ke pemerintah daerah dan juga menanggung pajak ekspor.

Hal lain yang merugikan petani adalah penentuan kualitas tembakau ditentukan secara sepihak oleh pembeli yang sifatnya sangat subjektif berdasarkan pada ukuran sensori (aroma, rasa, elastisitas, dan warna) sehingga harganyapun ditetapkan secara sepihak oleh pembeli. Standar mutu yang telah ditetapkan oleh instansi yang terkait dan lembaga tembakau, dinas perkebunan, dan gudanggudang pembelian setempat berupa standar monster pada setiap musim panen belum dapat dioperasionalkan secara efektif.

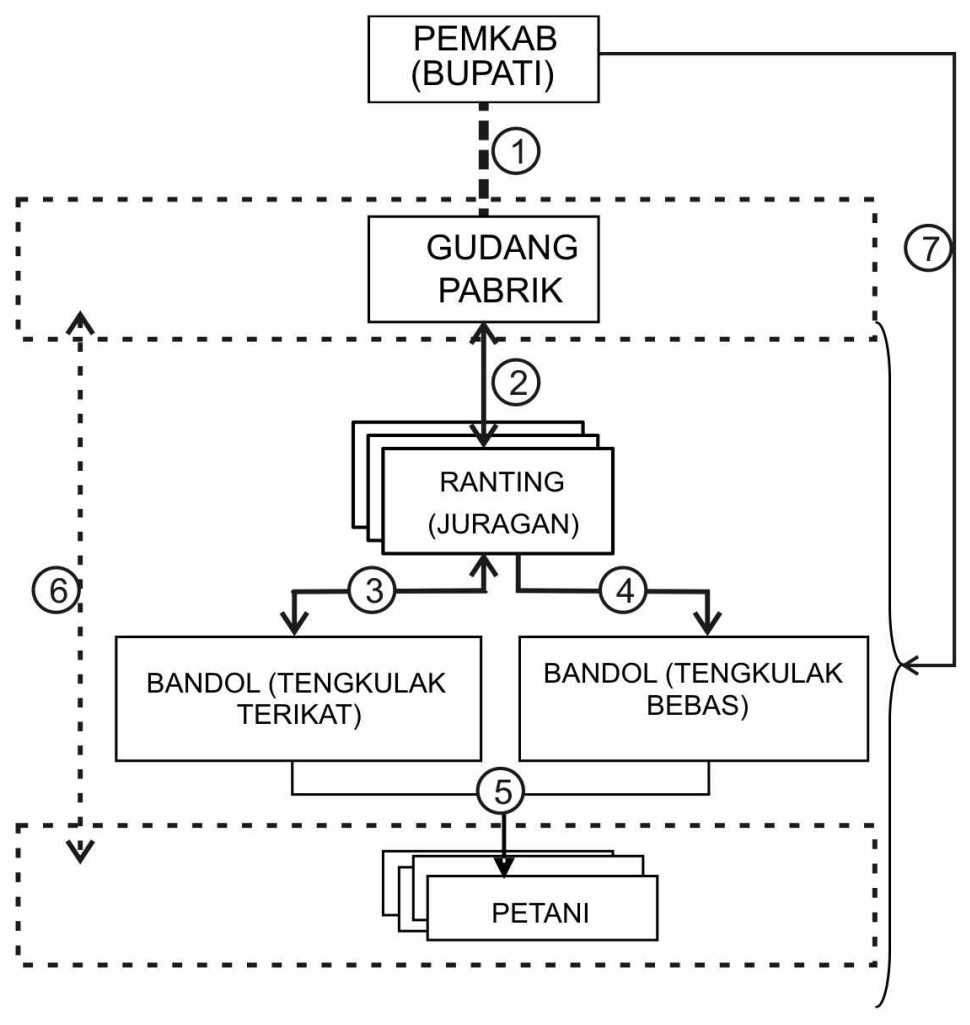

Gambar 1. Lembaga Pemasaran dan Hubungannya di Madura Sumber: Solfiyah et.al, 2009 
Fuad Hasan, Dwidjono H. D. : Prospek Dan Tantangan Usahatani Tembakau Madura...

Tabel 4. Rincian Margin Harga Tembakau Rajangan pada Saluran Pemasaran Tingkat I (Petani $\rightarrow$ Bandol $\rightarrow$ Ranting $\rightarrow$ Gudang)

\begin{tabular}{|c|c|c|c|c|}
\hline No & Keterangan & $\begin{array}{c}\text { Harga Rata-rata } \\
(\mathrm{Rp} / \mathrm{Kg})\end{array}$ & $\begin{array}{l}\text { Margin Harga } \\
(\mathrm{Rp} / \mathrm{Kg})\end{array}$ & $\begin{array}{c}\text { Prosentase } \\
(\%)\end{array}$ \\
\hline \multirow[t]{2}{*}{1} & Petani & & & \\
\hline & Harga tembakau & 11.456 & - & - \\
\hline \multirow[t]{3}{*}{2} & Bandol & & 4.144 & 9.10 \\
\hline & a. Harga beli & 11.456 & & \\
\hline & b. Harga jual & 15.600 & & \\
\hline \multirow[t]{3}{*}{3} & Ranting & & 8.538 & 18.75 \\
\hline & a. Harga beli & 15.600 & & \\
\hline & b. Harga jual & 24.138 & & \\
\hline \multirow[t]{4}{*}{4} & Gudang PR & & 32.862 & 72.15 \\
\hline & a. Harga beli & 24.138 & & \\
\hline & b. Harga jual ekspor & 57.000 & & \\
\hline & Total & & 45.544 & 100.00 \\
\hline
\end{tabular}

Tabel 5. Rincian Margin Harga Tembakau Rajangan pada Saluran Pemasaran Tingkat II (Petani $\rightarrow$ ranting $\rightarrow$ gudang)

\begin{tabular}{clccc}
\hline No & \multicolumn{1}{c}{ Keterangan } & $\begin{array}{c}\text { Harga Rata-rata } \\
(\mathrm{Rp} / \mathrm{Kg})\end{array}$ & $\begin{array}{c}\text { Margin Harga } \\
(\mathrm{Rp} / \mathrm{Kg})\end{array}$ & Persentase (\%) \\
\hline 1 & Petani & & & \\
& harga tembakau & 15.600 & & 20,62 \\
2 & Ranting & & 8.538 & \\
& a. Harga beli & 15.600 & & 79,38 \\
& b. Harga jual & 24.138 & & \\
3 & Gudang PR & & 32.862 & 100.00 \\
& a. Harga beli & 24.138 & & \\
& b. Harga jual & 57.000 & & \\
& Total & & 41.400 & \\
\hline
\end{tabular}

Sumber : Solfiyah et.al (2009)

Fluktuasi harga dari tahun ketahun selalu dijumpai bukan hanya karena produk yang dihasilkan memang berbeda, tetapi juga disebabkan oleh kurang adanya keseimbangan antara pasokan dengan kebutuhan. Menyediakan tembakau sesuai kebutuhan ternyata sangat sulit karena belum adanya data akurat yang disampaikan oleh pihak industri rokok mengenai rencana pembelian dan stok yang ada di pabrik (Isdijoso, 1999). Disamping itu, faktor yang mempengaruhi fluktuasi harga adalah adanya persaingan yang kurang sehat antara pembeli tembakau, terkait juga dengan saat buka dan tutupnya gudang-gudang pembelian tembakau di masing-masing tempat yang tidak diinformasikan terlebih dulu (Solfiah, 2009).

Rusaknya harga tembakau di Madura disinyalir juga dikarenakan adanya tembakau Jawa yang masuk ke gudang pabrik rokok di Madura. Meskipun sebenarnya Pemerintah daerah telah mengeluarkan perda tentang larangaan masuknya tembakau luar Madura. (Perda no 3/2002 tentang Pengendalian Mutu Tembakau). 


\section{Masalah Internal}

Permasalahan yang berasal dari petani adalah 1) bargaining position petani masih rendah karena belum maksimalnya peran kelembagaan petani seperti koperasi, asosiasi petani tembakau, dll; 2) rendahnya produktivitas karena secara teknis petani belum berproduksi secara efisien. Menurut Fauziyah et al (2010), bahwa sebagian besar petani tembakau di Kabupaten Pamekasan, belum mengalokasikan input secara optimal, sehingga belum mampu mencapai efisiensi teknis yang baik dan belum mampu menghasilkan produktivitas yang tinggi. Varietas yang digunakan petani seadanya, kualitas bibit kurang bagus, sumberdaya alam terutama air terbatas, tingkat kesuburan tanah yang rendah dan teknik budidaya yang dilakukan umumnya menggunakan teknologi yang diperoleh secara turun temurun dan masih sedikit yang menggunakan teknologi rekomendasi.

Produktivitas tembakau tegal dan gunung berkisar antara 250-300 $\mathrm{kg} / \mathrm{Ha}$ sedangkan tembakau sawah bisa mencapai 400$600 \mathrm{~kg} / \mathrm{Ha}$ (Murdiyati et.al, 1991). Namun demikian, pabrikan lebih menyukai tembakau gunung dibandingkan tembakau sawah karena tembakau gunung lebih beraroma dan kandungan kloritnya lebih rendah.

Tanaman tembakau merupakan salah satu tanaman budidaya yang sangat peka terhadap perubahan iklim terutama curah hujan dan serangan penyakit, sehingga pada kondisi iklim yang menyimpang terjadi kerusakan yang berat. Hal ini dialami pada musim tanam tahun 1998, dimana realisasi tanam $28.344 \mathrm{Ha}$, sedangkan yang dapat dipanen hanya $3.017 \mathrm{Ha}$ $(10,64 \%)$ karena iklim terlalu basah. Dalam kondisi iklim terlalu basah, petani tidak memanen daun tembakau untuk dirajang, tetapi membiarkan saja berada di lapang sampai kering di pohon menjadi tembakau kerosok, yang sering disebut tembakau "hang". Namun demikian, petani tembakau di Madura seakanakan sudah terikat tradisi untuk menanam tembakau betapapun besar risikonya karena memang pilihan komoditas alternatif relatif sedikit mengingat tanah di Madura umumnya kurang subur, airnya terbatas dan keuntungan besar jika berhasil.

\section{Alternatif Pemecahan}

Guna mengatasi permasalahan yang dihadapi usahatani tembakau, ada beberapa alternatife pemecahan yang bisa dilakukan:

Mengurangi Luas Areal Tanam Tembakau. Pengurangan dilakukan dengan menentukan spesifikasi lokasi yang cocok untuk tanaman tembakau dengan harapan kualitas dan produktivitas yang dihasilkan tinggi. Menurut Balai Penelitian Tembakau dan Tanaman Serat, penanaman tembakau di Kabupaten Sampang sebenarnya tidak dianjurkan karena kadar $\mathrm{Cl}$ tanah cukup tinggi.

Hasil pemetaan Dishutbun Pemkab Pamekasan, tahun 2012 kebutuhan areal tanam tembakau di Pamekasan sekitar 31 ribu hektar lebih. Meski, pada kenyataannya, petani cendrung over produksi. Apalagi, mereka mengacu pada kesuksesan musim tanam tahun sebelumnya.

Tanaman Pengganti Tembakau. Upaya mensubstitusi tanaman tembakau bukan merupakan hal yang mudah. Rahmat et al (2009) mengidentifikasi beberapa faktor yang menjadi kendala dalam substitusi tembakau, yaitu a) secara teknis, tanaman tembakau mempunyai keunggulan diusahakan pada lahan dan iklim yang kering; b) secara ekonomi, komoditas tembakau relatif mempunyai tingkat pendapatan usahatani yang tinggi dan tidak banyak komoditas yang menyamai tingkat pendapatan tersebut meskipun mempunyai derajat risiko tinggi pula;

Tabel 6. Produktivitas Tembakau Madura

\begin{tabular}{lcccc}
\hline Kabupaten & \multicolumn{3}{c}{ Tahun } \\
\cline { 2 - 5 } & 2006 & 2007 & 2008 & 2009 \\
\hline Sampang & 583 & 593 & 568 & 525 \\
Pamekasan & 695 & 530 & 581 & 381 \\
Sumenep & 649 & 460 & 566 & 490 \\
Jatim & 817 & 727 & 711 & 681 \\
\hline
\end{tabular}

Sumber: Deptan 
dan c) secara sosial, pada daerah tertentu komoditas tembakau merupakan komoditas yang telah secara turun temurun sehingga menjadi bagian budaya dari pola pertaniannya.

Komoditas substitusi yang direkomendasikan seharusnya memberikan keuntungan yang relatif sama paling tidak mendekati keuntungan tembakau dengan penerapan teknologi dan jaminan pasar. Tantangannya adalah sedikitnya alternatif komoditas yang sesuai dengan agroekologi Madura. Pada tahun 2010 telah dilaksanakan Program Pengembangan Agribisnis dengan kegiatan Penanganan Over Supply Tembakau Rakyat melalui subsidi usahatani komoditi alternatif. Tujuannya adalah untuk mengurangi areal tanaman tembakau sehingga dapat mengantisipasi over produksi tembakau di Jawa Timur yang dapat berdampak pada stabilitas harga tembakau, memberikan alternatif bagi petani tembakau untuk menanam komoditi non tembakau yang memiliki prospek baik. Data realisasi kegiatan Penanganan Over Supply Tembakau Rakyat melalui subsidi usahatani komoditi alternatif terlihat pada Tabel 7.

Pada tahun 2010, PTPN sudah membuat demplot untuk tanaman tebu di Kabupaten Pamekasan. Sebenarnya pernah dikembangkan tanaman tebu di Madura tetapi karena mahalnya transportasi untuk sampai ke pabrik gula yang ada di Surabaya maka akhirnya tidak berkembang. Dengan adanya suramadu diharapkan bisa memperlancar pengangkutan tebu ke Surabaya. Menurut Fauziyah (2010), ada beberapa tanaman yang sudah ditanam beberapa petani di Pamekasan untuk mengganti tanaman tembakau dengan hasil yang mendekati atau lebih besar dari hasil tanaman tembakau (Rp6-9 juta/Ha/musim) yaitu: bawang merah (Rp31,25 Juta/Ha/musim), tomat (Rp7,4 juta/Ha/musim), semangka (Rp11,5 juta/Ha/musim) dan melon (Rp13,5 juta/Ha/musim)

Budidaya Tanaman Tembakau Rendah Nikotin. Tembakau Madura yang dikembangkan saat ini mempunyai kadar nikotin 2-3,5\% (Anonim, 2007). Menurut peraturan pemerintah No. 38 Tahun 2000, batasan kandungan nikotin rokok adalah 1,5 $\mathrm{mg} /$ batang dan tar 2,0 mg/batang. Meskipun terbit lagi Peraturan Pemerintah yang baru No.19/2003 yang tidak lagi membatasi kadar nikotin dan tar pada rokok dimana salah satu alasannya bahwa rokok kretek yang berbahan baku tembakau rakyat tidak mungkin memenuhi syarat seperti pada Perpu sebelumnya (No.38/2000). Dengan peraturan yang baru, industri rokok hanya diwajibkan untuk menginformasikan kepada konsumen tentang kandungan nikotin dan tar pada setiap batang rokok yang diedarkan. Akan tetapi pemerintah telah mengesahkan RPP (Rancangan Peraturan Pemerintan) tembakau menjadi Peraturan Pemerintah No 109/2012 yang didalamnya memuat pasal tentang pengujian kadar nikotin dan tar.

Diversifikasi Produk Turunan Tembakau. Kelebihan penawaran tembakau untuk industri rokok dapat diolah menjadi produk olahan selain rokok. Oleh karena itu perlu dicari alternatif olahan berbahan baku tembakau, diantaranya adalah dengan mengekstrak daun tembakau menjadi minyak atsiri.

Berdasarkan pengujian menggunakan Kromatografi Gas (GC) oleh Stojanovic et al. (2000), minyak atsiri yang diekstrak dari tembakau tersusun oleh beragam komponen kimia. Minyak atsiri tersebut secara umum tidak lagi mengandung zat-zat kimia yang berbahaya, seperti nikotin. Keunggulan minyak atsiri tembakau sebagai senyawa yang bersifat

Tabel 7. Realisasi Kegiatan Penanganan Over Supply Tembakau Rakyat Melalui Subsidi Usahatani Komoditi Alternatif Tahun 2010

\begin{tabular}{llc}
\hline Kabupaten & Substitusi & Luas areal $(\mathrm{Ha})$ \\
\hline Jember & Kacang tanah & 20 \\
Sumenep & Benih jagung local & 55 \\
& Benih bawang merah & \\
Jumlah & & 75 \\
\hline
\end{tabular}

Sumber: Disbun Jatim, 2011 
Fuad Hasan, Dwidjono H. D. : Prospek Dan Tantangan Usahatani Tembakau Madura...

antimikroba, antioksidan, dan beraroma merupakan potensi yang dapat dikembangkan. Minyak atsiri tembakau memungkinkan pengolahan produk turunan tembakau menjadi beragam produk industri meliputi, farmasi, kosmetik, pembersih rumah tangga, dan lainnya.

Mengoptimalkan Kelembagaan Pertanian. Agar kegiatan usaha tani tembakau mempunyai produktivitas tinggi, lebih efisien, dan meningkatkan bargaining position petani maka kelembagaan pertanian yang sudah ada (BPP, koperasi, kelompok tani, asosiasi petani tembakau) perlu dioptimalkan. Kerjasama yang baik dalam wadah kelompok akan memungkinkan penerapan teknologi mutakhir oleh para petani anggota kelompok; karena bibit, pupuk; dan sarana produksi yang lain dapat diusahakan bersama, misalnya pengadaan pupuk, bibit, pestisida dapat sekaligus dibeli lewat KUD, bibit tembakau bisa disemai secara bersama secara kolektif, dll. Selanjutnya kelompok tani dapat membentuk hamparan luas yang akan lebih mudah menerapkan teknologi tepat guna spesifik lokasi sesuai anjuran. Keuntungan lain dari berfungsinya kelompok hamparan adalah terbentuknya kekuatan petani dalam menghadapi pasar karena produk yang dihasilkan akan seragam mutunya dalam kuantitas yang cukup besar.

\section{SIMPULAN}

Legalisasi pembatasan produksi maupun pemasaran rokok akan menurunkan permintaan tembakau yang mengharuskan petani mempersiapkan diri untuk mengurangi areal tanam, menanam tembakau rendah nikotin dan mencari komoditas alternative sebagai penggantinya. Zonasi pemetaan areal tanam tembakau menajadi hal penting guna membatasi luasan tanam dengan memperhatikan agroekologi yang tepat diiringi dengan pengemembangan tembakau rendah nikotin beserta alternative produk turunannya.

\section{DAFTAR PUSTAKA}

Anonim, 2007. Akselesrasi Alih Teknologi Tembakau Madura Rendah Nikotin. Warta penelitian dan pengembangan Pertanian No.39.Vol.3: 10-11. Balai Penelitian Tanaman Tembakau dan Serat. Malang

BPS, 2011. Jawa Timur dalam Angka. BPS. Surabaya

Fauziyah, E.,2010. Pengembangan Pertanian pada Daerah Sentra Produksi Tembakau di kabupaten Pamekasan. Jurnal Embryo Vol.7 No.2:117-179. Fakultas Pertanian Universitas Trunojoyo.

Fauziyah, E., Sri H.,Nunung K., Sri U.K.,2010. Analisis Produktivitas Usahatani Tembakau di Kabupaten Pamekasan. Jurnal Organisasi dan Manajemen Vol.6 No.2: 119-131.

Isdijoso, S.H, Mulkani, Heri I, dan Slamet, 1999. Usahatani, Kelembagaan, dan Pemasaran Tembakau Madura dalam Tembakau Madura. Balai Penelitian Tembakau dan Tanaman Serat. Malang.

Murdiyati, AS.,G. Dalmadyo, Mukani, Suwarso, SH., Isdiyoso, A. Rahman, dan B. Hariadi, 1991. Observasi Lahan Madura. Balittas. Malang p.31

Rachmat, Muchjidin, dan Sri Nuryanti, 2009. Dinamika Agribisnis Tembakau Dunia dan Implikasinya Bagi Indonesia. Forum Penelitian Agro Ekonomi Vol.7 (2): 73 91. PSEKP. Deptan

Solfiyah R.,S.Sobari, dan F.Hasan. 2009. Kegagalan Pasar dalam Sistem Tataniaga Tembakau Madura. Jurusan Agribisnis. Fakultas Pertanian Universitas Trunojoyo. Skripsi 